\title{
AL-A'RAF
}

Jurnal Pemikiran Islam dan Filsafat

\section{SURAKARTA http://ejournal.iainsurakarta.ac.id/index.php/al-araf}

ISSN: 1693-9867 (p); 2527-5119 (e)

DOI: $10.22515 /$ ajpif.v14i1.707

\section{TAFSIR ALQUR'AN PARADIGMA INTEGRATIF: STUDI ATAS QIRA'AH ALTHANIYAH MUHAMMAD SYAHRUR}

\author{
Abdul Malik \\ UIN Sunan Kalijaga, Yogyakarta
}

\begin{tabular}{l}
\hline \\
\hline Keywords: \\
Qur'anic- \\
interpretation, \\
Alternative- \\
reading, Alqur'an \\
and Sains \\
\hline
\end{tabular}

\begin{abstract}
Abstrak
Artikel ini membahas mengenai pembacaan alternatif (qira'ah altaniyah) terhadap Alqur'an yang ditawarkan oleh Muhammad Syahrur dalam karyanya, “Alkitab wa Alqur'an: Qira'ah Almu'ashirah”. Melalui karya ini, Syahrur menawarkan metode tafsir integratif, yang dibangun dengan memadukan analisis ilmu alam, ilmu sosial, dan ilmu tafsir. Melalui pendekatan analisis deskriptif atas karya tersebut, studi ini menemukan dua poin penting, (I) Syahrur menggunakan analisis matematika dalam menafsirkan ayat muhkamat, dan analisis sains untuk ayat mutasyabihat. (2) Hudud merupakan hasil dari tafsir integrasi analisis bahasa dan matematika dalam memahami ayat hukum, sedangkan ta'wil ilmi merupakan pemahaman terhadap ayat mutasyabihat seperti: penurunan wahyu, dengan analisis kognisi ilmu alam.
\end{abstract}

\section{Abstract}

This article describes on the alternative reading (qira'ah altaniyah) of Alqur'an proposed by Muhammad Shahrur, in his work "Alkitab wa Alqur'an: Qira'ah Almu'ashirah". Through this work, Syahrur proposed an integrative-interpretation method which is built through combining analysis of natural science, social science, and tafsir. Based on the descriptive analysis approach to this works, this study found out two important things: (1) Syahrur using mathematical analysis to interpret the muhkamat's verses and science analysis for mutasyabihat's verses. (2) Hudud is a result of the integrative analysis interpretation based on the linguistic and mathematic analysis in understanding the Quranic verses about the law, while ta'wil ilmi is an understanding toward mutasyabihat verses, like the revelation, which is based on the analysis of natural science cognitive. 


\section{Pendahuluan}

Alqur'an diturunkan oleh Allah sebagai pedoman hidup dan petunjuk bagi manusia. ${ }^{1}$ Fazlur Rahman menyebut Alqur'an sebagai dokumen keagamaan dan dokumen sosial. ${ }^{2}$ Sebagai sebuah dokumen, Alqur'an tidak berbicara sendiri dalam memberikan petunjuk. Manusialah yang sejatinya bertanggungjawab membuat Alqur'an aktif berbicara, sehingga dapat berfungsi sebagai sebuah petunjuk. ${ }^{3}$ Dengan posisinya sebagai petunjuk tersebut, Alqur'an mendapatkan porsi kajian yang beragam dari para pemikir Muslim, baik dari segi teoritis-metodologis maupun praksisimplementatif.

Selama satu dekade terakhir, kajian Alqur'an menunjukkan perkembangan metode dan pendekatan yang beragam dari para pemikir Muslim. Salah satunya adalah Muhammad Syahrur (1938). Ia turut hadir menawarkan pendekatan yang relatif baru dalam kajian Alqur'an memalui karya monumentalnya, Alkitab wa Alqur'an: Qira'ah Almu'asirah. ${ }^{4}$ Kata "Qira'ah Almu'asirab (pembacaan kontemporer)" dalam karyanya ini merupakan kritik terhadap model pembacaan yang mengulang-ulang (qira'ah tikerariyah) dan pembacaan ideologis (qira'ah taqlidiyyah). Dengan konsep Qira'ah Almu'asirah, Syahrur bermaksud menawarkan sebuah pembacaan alternatif (qira'ah ath-thaniyah) terhadap Alqur'an dalam konteks aktual-kontemporer.

Hal menarik dari gagasan tafsir Alqur'an menurut Syahrur di sini, salah satunya adalah tafsir modern dengan sentuhan analisis matematika (matematic analysis) dan sains (scientific analysis). Analisis matematika digunakan sebagai pola analisis dalam memetakkan ayat-ayat hukum,

\footnotetext{
Q.S. Albaqarah [2]: 2 dan 185.

2 Fazlur Rahman, Tema-Tema Pokok Alqur'an (Bandung: Pustaka, 1983), 1.

3 Aksin Wijaya, Arah Baru Studi "Ulum Alqur"an: Memburu Pesan Tuhan di Balik Fenomena Budaya (Yogyakarta: Pustaka Pelajar, 2009), 1.

4 Muhammad Syahrur, Alkitab Wa Alqur'an; Qira'ah Almu'asirah (Damaskus: alAhali li al-Tiba'ah wa al-Nasyr wa al-Tauzi', 1990).
} 
sedangkan analisis sains sebagai metode dalam memahami Alqur'an dalam menakwilkan ayat yang menurut kategorisasinya sebagai ayat mutasyabihat, yang disebutnya sebagai ta'wil al-'ilmi.

Melalui tawaran analisis tersebut, Qira'ah Almu'asirah yang dimaksud Syahrur mencoba melakukan pembacaan integratif terhadap Alqur'an yang memadukan analisis ilmu tafsir sebagai pemahaman ilmu awal dengan analisis matematika dan sains yang mewakili pemahaman atau pemikiran kekinian. Artikel ini membahas pemikiran dan gagasan Muhammad Syahrur mengenai kajian kontemporer terhadap Alqur'an, dengan fokus kajian utama pola penafsiran yang mengintegrasikan ilmu sains dengan ilmu tafsir dalam menggali pesan Alqur'an.

Karya Syahrur, Alkitab wa Alqur'an: Qira'ah Almu'asirah akan dijadikan obyek kajian utama, di samping karyanya yang lain. Pendekatan dan analisis yang digunakan dalam kajian ini adalah analisis deskriptif. Fokus pembahasan bukanlah model kajian kitab tafsir (mabahis fi kutub at-tafsir) sebagaimana teori az-Zahabi dalam Tafsir Almufassirun, ${ }^{5}$ melainkan berupa kajian teoritis-analitis terhadap pemikiran Muhammad Syahrur dalam karyanya, dengan titik pencarian pada gagasan dan idenya mengenai Alqur'an dan penafsiran.

Pemikiran Syahrur tentang paradigma tafsir integratif, yang memadukan analisis ilmu tafsir dengan sains memang masih belum menemukan format baku. Tetapi, melalui kajian pemikiran Syahrur ini diharapkan bisa menjadi gambaran awal terbentuknya paradigma tafsir integratif bagi Alqur'an. Memainkan peran analisis dua keilmuan dalam memahami Alqur'an bukanlah hal mudah, namun diskursus tersebut dapat ditemui dalam pemikiran Syahrur.

5 Muhammad Husein Az-Zahabi, At-Tafsir Wa Almufassirun (Cairo: Maktabah Wahbah, n.d.). 


\section{Konfigurasi Intelektual Muhammad Syahrur dan Karyanya}

Muhammad Syahrur adalah seorang profesor Teknik Sipil. Ia dilahirkan di Damaskus (Syiria) pada 11 April 1938, dengan nama lengkap Muhammad Syahrur al-Dayyub. Keluarga Syahrur murni keturunan dan berkebangsaan Damaskus, Suriah. ${ }^{6}$ Masa dewasa Syahrur tidak lepas dari sejarah masa kecilnya yang dibesarkan dalam lingkungan keluarga yang berfikir kritis dalam beragama. ${ }^{7}$

Sikap keberagamaan ayah Syahrur bisa dibilang unik. Walaupun secara penampilan berwajah agamis-dengan pakaian khas keislaman Timur Tengah—namun ia memiliki pola pikir modern, pola pikir keagamaan yang sadar akan realitas kehidupan yang dihadapi. Pola pikir ayahnya ini banyak membentuk Syahrur, baik dalam karakter akademis maupun sosial. Sebagaimana diakui oleh Syahrur, suatu hari ayahnya mengajarkan bahwa beribadah pada Tuhan sama pentingnya dengan kejujuran, kerja, dan mengikuti hukum alam. Selain itu, Syahrur juga selalu ingat dengan ilustrasi yang diberikan oleh ayahnya mengenai agama, "Jika kamu ingin menghangatkan tubuh, jangan membaca Alqur'an, tapi nyalakan api di tungke'".

Ilustrasi ayahnya ini dijadikan prinsip kesadaran berpikir oleh Syahrur, termasuk juga ketika akhirnya ia mulai menggeluti kajian Alqur'an. Dalam banyak hal, Syahrur terlihat berbeda dengan kebanyakan pemikir Alqur'an kontemporer lainnya. Kekhasan tersebut telihat pada kemampuan Syahrur dalam menggunakan — atau memadukan-pisau analisis sains dan keilmuan tafsir untuk memahami pesan Alqur'an.

Dari segi pendidikan formal, Syahrur memang tidak concern terhadap kajian keislaman (islamic studies). Ia lebih concern dalam bidang teknik, hingga meraih jenjang doktor dibidang yang sama, Mekanika Pertahanan dan 287.

${ }^{6}$ Kurdi dkk, Hermenetika Alqur'an dan Hadith (Yogyakarta: Elsaq Press, 2010),

Dale F. Eickelman, "Interview with Muhammad Sahahrur," in The Qur'an, Morality and Critical Reason: The Essential Muhammad Shahrur, ed. Andreas Christmann (Leiden: Brill, 2010), 502.

8 Dale F. Eickelman, The Qur'an, Morality and Critical Reason: The Essential Muhammad Shabrur, 502. 
Fondasi (Mikanika Turbat wa Asasat). ${ }^{9}$ Sejarah intelektual Syahrur memang secara formal beralurkan sains. Karena itu, beberapa kritikus melemparkan premis, seharusnya Syahrur lebih tepat dipandang sebagai ahli ilmu eksak dibandingkan sebagai pemikir atau cendikiawan Muslim (mufassir).

Pandangan tersebut tidak menyurutkan semangat Syahrur dalam mengkaji Alqur'an. Ia tetap menggeluti kajian Alqur'an dan aktif dalam aktivitas pemikiran keislaman diSuriah. Perjalanan akademis ini membentuk kepribadian Syahrur, kepedulian sosial, serta pemikiran terhadap agama dan perubahan. Dalam perjalanannya, ia pun berkenalan dengan filsafat dan kajian Alqur'an. Sehingga ia pun pernah menjadi konsultan negara Arab dan menjadi peserta kehormatan dalam debat publik mengenai keislaman di Lebanon dan Maroko.

Peletakan dasar intelektualitas Alqur'an Syahrur dapat dilacak dalam sejarah pendidikan keagamaannya. Meski secara formal fokus studi Syahrur jauh dari disiplin keilmuan Alqur'an, tetapi tidak berarti ia tidak menggeluti kajian Alqur'an sama sekali. Seperti kebanyakan pemikir Islam lainnya, Syahrur juga dibesarkan dalam lingkungan sekolah Islam. Selain bahasa Arab, ia juga menguasai bahasa Inggris, Rusia, dan lain-lain. Ketertarikannya terhadap kajian keislaman (khususnya Alqur'an) semakin besar sejak dirinya berada di kota Dublin, Irlandia (1970-1980) untuk mengambil program Magister dan Doktor. Di sana, Syahrur merasakan adanya "benturan peradaban" antara latar belakang teologisnya sebagai seorang Muslim, dengan fenomena sosial-intelektual-kemasyarakatan yang ada. ${ }^{10}$

Perjalanan intelektualnya di Moskow adalah masa awal yang mengantarkan Syahrur berkenalan dengan teori dan praktek Marxis. Ia mulai akrab dengan tradisi kajian strukturalisme linguistik yang digagas

Syahrur, Al-Kitab Wa Alqur'an; Qira'ah Almu'asirah, 823. Ahmad Zaki Mubarok, Pendekatan Strukturalisme Linguistik dalam Tafsir Alqur'an Kontemporer Ala Syahrur (Yogyakarta: Elsaq, 2007), 139.

10 Ahmad Fawaid Syadzily, "M. Syahrur; Figur Fenomenal dari Syiria," Islamlib. com, last modified 2014, www.islamlib.com. 
Ferdinand De Saussure. ${ }^{11}$ Perhatiannya terhadap bidang teknik, tidak mengahalanginya untuk mendalami disiplin ilmu lain seperti: filsafat, linguistik, Alqur'an, studi agama, dan lainnya. Perhatiannya pada kajian Alqur'an pun semakin besar setelah bertemu dengan Ja'far Dakk al-Bab di Irlandia, rekan satu almamater sekaligus teman seprofesinya sebagai dosen di Universitas Damaskus. Sebagai seorang yang ahli dalam kajian linguistik, Syahrur banyak belajar darinya. ${ }^{12}$

NarasiperjalananintelektualSyahruryang singkatinimemperlihatkan, bahwa karir intelektualitas sains dan Alqur'an yang dicapai Syahrur berjalan bergandengan. Intelektualitas sainsnya ditempuh secara formal, sedangkan intelektualitas Alqur'an ditempuh dengan cara otodidak, dan belajar kepada ahli secara non-formal. Jika keahliannya di bidang sains didukung dengan kemahirannya dalam ilmu-ilmu eksak seperti: Matematika, Fisika, Kimia, dan lain-lain, maka keahliannya di bidang Alqur'an didukung oleh penguasaannya terhadap beberapa bahasa dunia, seperti Arab, Inggris, Perancis, dan Rusia. Inilah modal besar Syahrur dalam mengkaji keilmuan Islam dan sosial, termasuk filsafat. ${ }^{13}$

Perpaduan minat intelektual Syahrur dalam bidang sains dan Alqur'an mempengaruhi dan membentuk pola pikir, serta pilihan metodologi Syahrur dalam memahami teks-teks keagamaan (khususnya Alqur'an, Hadith, dan Fiqh). Dalam beberapa teori penafsiran Alqur'an yang digunakannya, Syahrur terlihat memainkan kemahirannya dalam bidang sains, bahkan membentuk teori tafsir baru yang memadukan analisis sains dan tafsir. Beberapa teorinya banyak dikenal dalam studi Alqur'an, seperti: teori limit, differensial, integral, ta'wil ilmi dan lainnya. Termasuk yang paling populer adalah teori baru dalam memahami ayat hukum, yaitu teori limitmatematis (nazariyat al-budud). ${ }^{14}$

11 Ahmad Zaki Mubarok, Pendekatan Struktualisme Linguistik dalam Tafsir Alqur'an Kontemporer Ala Syabrur, 138.

12 Kurdi, dkk, Hermenetika Alqur'an dan Hadith, 287.

13 Kurdi, dkk, Hermenetika Alqur'an dan Hadith, 287.

14 Mubarok, Pendekatan Struktualisme Linguistik dalam Tafsir Alqur'an Kontemporer Ala Syahrur, 139. 
Dengan gagasan dan teori dimunculkan, pakar di bidang teknik sipil ini pada akhirnya tercatat sebagai pembaru kajian Alqur'an dan keislaman, baik secara teoritis maupun praksis. Karya yang dihasilkan dari "proyek" pembaharuan pemikiran keislaman kontemporer antara lain: (1) Alkitab wa Alqur'an: Qira'ah Almu'asiirah (Alkitab dan Alqur'an: Pembacaan Kontemporer), memuat gagasan pembaharuan pembacaan Islam. ${ }^{15}$ (2) Dirasat Islamiyyah Mu'asirah fi al-Daulah wa al-Mujtama' (Kajian Islam Kontemporer tentang Negara dan Masyarakat), berisi gagasan seputar tema-tema sosial dan politik terkait dengan persoalan warga negara (civil society) maupun negara (state). (3) AlIslam wa al-Iman: Manzumat Alqiyam (Islam dan Iman: Aturan-aturan Pelaksanaan), gagasan yang mencoba mendekonstruksi konsep klasik mengenai pengertian dan pilar-pilar (arkan) Islam dan Iman. (4)Nabwa Usul Aljadidah li al-Figh al-Islami Fiqh Almar'ah: al-Wasiyyah, al-Irs, Alqiwamah Alta'addudiyah, Allibas (Asas-asar baru untuk fikih Islami, fikih perempuan: wasiat, warisan, perwalian, pakaian), kitab ini mewakili manifestasi pemikiran feminis Syahrur. (5). Tajfif Manabi' Alirhab. Kitab ini berisikan kritikan dan bantahan Syahrur terhadap pembacaan Alqur'an ditemuinya. Ia banyak membantah penafsiran konsep-konsep kunci dalam Alqur'an yang ditawarkan oleh kalangan Islam radikal dan kelompok skripturalis-literalis. ${ }^{16}$ Dan (6) The Qur'an, Morality, and Critical Reason: The Essential Muhammad Syahrur (Qur'an, Moral, dan Alasan kritis: pikiran-pikiran inti Muhammad Syahrur). Buku yang diselesaikan atas bantuan dari Andreas Chrisman ini berisikan percikan pemikiran Syahrur, mulai dari masalah iman dan Islam, sunnah Nabi, wahyu, teori batas, kedudukan perempuan dalam hukum Islam dan masalah politik Islam. ${ }^{17}$

15 Setelah mengarang selama 20 tahun, Syahrur memutuskan untuk menerbitkannya. Syahrur mendapatkan banyak kritik dari para ulama atau sarjana Islam Timur Tengah, di antaranya: Mahir al-Munajjad yang mengkritik Syahrur lewat karyanya: Munaqasyat Alisykaliyah Almanhajiyyah fi Alkitab wa Alqur'an; Dirasah Naqdiyyah. Muhammad Munir asy-Syawwaf dalam karyanya: Tahafut Alqira'ah Almu'asirah.

16 Sahiron Syamsuddin dkk., Hermeneutika Alqur'an Madzab Yogya (Yogyakarta: Islamika dan Forstudia, 2003), 255-256.

17 Andreas Christmann, "Read the Qur'an As If It Was Revealed Last Night: An Introduction to Muhammad Shahrur's Life and Work," in The Qur'an, Morality and Critical 


\section{Gagasan Muhammad Syahrur Mengenai Alqur'an}

Dalam melakukan kegiatan penafsiran, Alqur'an menempati posisi sebagai objek penafsiran. Dengan posisinya sebagai obyek, Syahrur berpendapat bahwa umat Islam saat ini tidak harus terkungkung oleh hasil penafsiran para mufassir masa lalu. Penafsiran masa lalu merupakan produk historis yang mengandung kemungkinan tidak sesuai lagi dengan masa sekarang.

Syahrur menawarkan sikap: "kita harus bersikap seakan-akan baru saja menerima Alqur'an langsung dari Nabi Muhammad SAW". ${ }^{18}$ Pernyataan Syahrur ini diungkapkan sebagai upaya untuk menyadarkan masyarakat Muslim bahwa realitas hidup sekarang berbeda dengan zaman Nabi. Karena itu, jika ingin membumikan nilai agama yang salib likulli raman wa makan (sesuai dengan ruang dan waktu), maka merupakan suatu keharusan untuk memahami teks agama dengan paradigma kekinian, serta berpegang pada prinsip kontemporaritas dan relevensi teks. ${ }^{19}$

Dengan menekankan pada landasan realitas kekinian, seorang mufassir bagi Syahrur harus terlebih dahulu melihat dan memetakkan problem kajian keislaman kontemporer, mulai dari konfigurasi kajian, hingga kritik. ${ }^{20}$ Dengan kritikan ini, Syahrur kemudian menawarkan prinsip teoritis yang ia pegang dalam melakukan penafsiran Alqur'an. Prinsip ini menjadi pegangan Syahrur dalam berbagai ide pembaruannya, baik dalam kajian Alqur'an maupun kajian fikih kontemporer. Beberapa prinsip teoritis Syahrur yang menjadi pegangan antara lain: prinsip diferensiasi kata, prinsip holistik (tarti), kontekstualisasi penafsiran, otonomisasi teks, dan anti sinonimitas. ${ }^{21}$

Reason, ed. Andreas Christmann (Leiden: Brill, 2010), xvii-xviii. “

18 Abdul Mustaqim, dkk., Studi Alqur'an Kontemporer (Yogyakarta: Tiara Wacana, 2002), 137.

19 Muhammad Syahrur, Alkitab Wa Alqur'an; Qira'ah Almu'asirah, 44.

20 Muhammad Syahrur, Alkitab Wa Alqur'an; Qira'ah Almu'asirah, 30-32.

21 Abdul Mustaqim, dkk., Studi Alqur'an Kontemporer, 135-163. 
Syahrur melakukan penafsiran kembali terhadap beberapa poin terkait dengan Alqur'an, sehingga tampak memiliki konsepsi sendiri, yang menjadi pegangan pribadi dan dijadikan kajian oleh pegiat studi Alqur'an kontemporer.

\section{Kesadaran Integrasi Tafsir dengan Keilmuan Modern}

Dalam diskursus Qur'anic Studies, tradisi Islam mengenal dua teori interpretasi terhadap teks Alqur'an, tafsir, dan ta'wil. Agar kedua teori interpretasi ini tetap berkembang, maka kebutuhan pengembangan metodologi pembacaan menjadi keniscayaan adanya. Proyek besar yang digagas oleh Syahrur dalam memperbarui pembacaan teks agama (divine text) terbangun dari semangat pemikir kontemporer yang ingin melahirkan teori pembacaan baru terhadap Alqur'an. Ini yang menjadi motivasi kuat, sehingga Alkitab wa Alqur'an: Qira'ah Almu'asirah ditulis oleh Syahrur.

Syahrur menggunakan kata "Qira'ah Mu'asirab" bukan Tilawah, karena kata "Qira'ah Mu'asirah" berarti membaca teks agama yang turut memberikan andil terhadap realitas kekinian yang dihadapi, ${ }^{22}$ sehingga membaca Alqur'an tidak hanya berhenti pada pelafalan. Selain itu, Syahrur juga menggunakan istilah ini kritik terhadap model pembacaan Alqur'an yang berputar pada pembacaan repetitif (Qira'ah Tikrariyah) dan pembacaan ideologis (Qira'ah Taklidiyyah). Membaca Alqur'an bukan hanya sekadar membaca saja sebagaimana membacanya Alqur'an oleh para Qari', melainkan membaca dengan memahaminya untuk konteks kekinian, menggunakan ilmu kekinian.

Dalam menggagas proyek pembacaan kontemporer terhadap Alqur'an ini, Syahrur memberikan penegasan mengenai hakikat tafsir/ ta'wil yang sejatinya diperlukan dalam masa kontemporer ini. ${ }^{23}$ Syahrur mengatakan:

22 Muhammad Syahrur, Nahwa Ushul Aljadidah Li Fiqhi Alislami; Figh Almar'ah (Damaskus: al-Ahali li al-Tiba'ah wa al-Nasyr wa al-Tauzi', 2000), 117.

23 Muhammad Syahrur, Alkitab Wa Alqur'an; Qira'ah Almu'asirah, 47-48. 
"All interpretation, including tafsir (exegesis) or ijtihad (independent reasoning) are no more than buman attempts toward understanding and acting on this divine text"24

"Semua penafsiran, termasuk tafsir (penafsiran teks agama) atau ijtihad (penelaran mandiri dalam aktifitas istinbat) tidak lebih dari usaha manusia untuk memahami dan bertindak mengenai teks ketuhanan ini "

Kutipan di atas menjadi prinsip Syahrur, bahwa tidak ada tafsir yang sifatnya sakral, tafsir dibuat dalam konteks waktu dan kesejarahan. Karena konteks dan kesejarahan menjadi titik penekanan, maka bagi Syahrur masa kontemporer pun semestinya melahirkan tafsir yang berbeda dengan masa sebelumnya, seiring dengan berkembangannya keilmuan dan intelektualitas mufassir itu sendiri. Berkembangnya keilmuan menjadi jalan mulus lahirnya tafsir baru. Keilmuan apapun itu bisa digunakan sebagai jalan yang membantu memahami ayat Alqur'an. Bagi Syahrur, dikotomi keilmuan adalah hal yang tidak semestinya terjadi, karena hakikat keilmuan adalah bagaimana berpikir, dan hakikat pemikiran seorang Muslim adalah bagaimana ia berusaha memahami kitab suci agamanya. Dengan demikian, penegasan paradigma integratif menjadi jembatan bagi lahirnya Qira'ah Almu'asirah (pembacaan baru) tersebut.

Gagasan Syahrur di atas, merupakan upaya untuk menjembatani dan memberikan titik temu interaksi ilmu Alqur'an dengan keilmuan modern, termasuk golongan ilmu-ilmu alam dan sosial. Dengan demikian, sebagai mufassir yang hidup di dunia kontemporer, ada beberapa hal yang perlu diketahui terkait dengan menafsirkan Alqur'an, ${ }^{25}$ antara lain: (1) semua keilmuan kontemporer yang digunakan sebagai ilmu bantu mengkaji Alqur'an, tidak akan mengurangi sakralitas Alqur'an itu sendiri. Alqur'an adalah kalam Allah SWT yang akan tetap sakral, dan pembacaan terhadapnya hanyalah sebuah usaha manusia untuk memahami. (2) akal

${ }^{24}$ Sahiron Syamsuddin, dkk., Hermeneutika Alqur'an Madzab Yogya, 257.

25 Muhammad Syahrur, Alkitab Wa Alqur'an; Qira'ah Almu'asirah, 44-45. 
memiliki peran aktif dalam menggali makna Alqur'an. (3) akal, wahyu, dan realitas merupakan tiga entitas yang terkait. ${ }^{26}$

\section{Paradigma Tafsir Integratif ala Syahrur}

Tiga prinsip di atas merupakan kesadaran awal yang perlu dibangun oleh setiap mufassir. Dengan prinsip ini, seorang mufassir harus mampu mendialogkan antara teks yang ditafsrikan dengan realitas yang ada di masyarakat, serta tafsir yang sesuai dengan taraf kehidupan sosial dan perkembangan ilmu pengetahuan. Dengan demikian, tafsir yang dihasilkan memiliki agenda mengatasi problematika yang sedang dihadapi, bukan mengulang tafsir yang sudah ada. ${ }^{27}$ Pengulangan tafsir hanya akan meriwayatkan pendapat sebelumnya, bukan menafsirkan Alqur'an dengan menyapa ilmu lain.

Tafsir bagi Syahrur setara dengan ijtihad, yakni upaya untuk memahami teks agama. Bagi Syahrur, tafsir yang digunakan dalam memahami ayat-ayat mubkamat, atau ayat yang masuk dalam kategori kitab ar-risalah. ${ }^{28}$ Pendekatan yang digunakan pun beragam, tergantung pada mufassimya. Dalam tafsir atau ijtihad, Syahrur sendiri menggunakan banyak pendekatan, mulai dari filosofis-linguistik, hingga linguistik-matematis, atau dikenal juga dengan teori batas (nazariyat Alhudud). ${ }^{29}$

Fungsi tafsir, atau ijtihad bagi Syahrur adalah untuk memahami kitab ar-risalah. Maka untuk memahami pesan risalah harus menggunakan metode yang sesuai dengan perkembangan zaman, termasuk perkembangan keilmuan. Implementasi yang jelas diberikan Syahrur ketika memahami muatan ayat dalam kitab ar-risalah, ayat-ayat hukum. Ia memahaminya

${ }^{26}$ Ahmad Zaki Mubarok, Pendekatan Strukturalisme Linguistik dalam Tafsir Alqur'an Kontemporer Ala Syahrur, 168.

27 Muhammad Syahrur, Nabwa Ushul Aljadidah Li Fiqhi Alislami; Fiqh Almar'ah, 60-61.

28 Abdul Mustaqim, dkk., Studi Alqur'an Kontemporer, 208.

29 Abdul Mustaqim, Epistemologi Tafsir Kontemporer (Yogyakarta: LKiS, 2010), 208. 
dengan teori limit-matematis (nazariyat al-budud) yang merupakan perpaduan antara analisis bahasa dengan teori matematika. ${ }^{30}$

Pendekatannya Syahrur yang cenderung semantis ini hendak menunjukkan kepada publik bahwa penghampiran melalui gramatika bahasa cukup potensial untuk mendinamisasikan kata dan kalimat dalam Alqur'an. Pendekatan kebahasaan tetap bisa dipakai untuk melahirkan tafsir-tafsir keislaman yang progresif, liberatif, dan humanis. Dengan pendekatan semantis-matematis tersebut, Syahrur mencoba menata kembali dan mereposisi beberapa hukum kanonik yang sudah berjalan, seperti: potong tangan, rajam, waris, kepemimpinan perempuan, poligami, aurat, dan sebagainya.

Syahrur melihat bahwa tafsir atau ijtihad begitu penting di masa sekarang, karena banyaknya persoalan yang tidak terdapat perjelasannya dalam teks. Persoalan kehidupan selalu berkembang, sedangkan teks Alqur'an telah berakhir (inna al-bawadis la tantabi wa an-nusus tantabi). ${ }^{31}$ Dengan itu, maka menjadi penting bagi mufassir untuk menanamkan prinsip, bahwa akal, wahyu, dan realitas saling terkait. Tafsir tidak saja mengandalkan proses pengulangan dari tafsir yang ada, melainkan rasionalisasi pemahaman wahyu itu yang justru dibutuhkan dalam menghadapi dan mengendalikan realitas tersebut. ${ }^{32}$

\section{Paradigma Ta'wil Integratif ala Syahrur}

Selain menawarkan teori batas (nazariyat al-budud), yakni pengklasifikasian pemahaman hukum dalam Alqur'an dengan polarisasi matematis dalam studi matematika, Syahrur juga menawarkan paradigma

${ }^{30}$ Muhammad Syahrur, Alkitab Wa Alqur'an; Qira'ah Almu'asirah, 453-467.

31 Christmann, "Read the Qur'an As If It Was Revealed Last Night: An Introduction to Muhammad Shahrur's Life and Work."Andreas Christmann, "The Form is Permanent but The Content Moves," in The Qur'an, Morality and Critical Reason, ed. Andreas Christmann (Leiden: Brill, 2010), 263-264.

32 Ahmad Zaki Mubarok, Pendekatan Strukturalisme Linguistik dalam Tafsir Alqur'an Kontemporer Ala Syahrur, 168. 
integratif dalam memahami Alqur'an melalui ta'wil 'ilmi, menakwilkan ayat Alqur'an dengan analisis sains. Alqur'an menggunakan ta'wil dalam obyek ayat-ayat mutasyabihat yang masuk dalam kategori kitab an-nubuwwah. Namun ta'wil yang dimaksud Syahrur adalah ta'wil ilmi atau ta'wil saintifik, ${ }^{33}$ bukan ta'wil dalam maksud memahami ayat Alqur'an dengan cara mengalihkannya ke makna lain karena adananya qarinab. ${ }^{34}$ Ayat-ayat yang masuk dalam kategori mutasyabihat, bagi Syahrur harus di-ta'wil sesuai dengan perkembangan pengetahuan manusia. ${ }^{35}$

Ta'wil bagi Syahrur semacam melakukan rekognisi atau bayangan ulang guna memahamkan sebuah makna/fenomena dalam Alqur'an. Dengan itu, maka mufassir perlu menganalisis imajinasi konteks sosial masyarakat. ${ }^{36}$ Salah satu contoh ta'wil Syahrur yang paling berbeda dengan pemikir lainnya adalah memahami ulang kata kunci inzal dan tanzil, yang selama ini menurutnya cenderung dimaknai monoton. Dalam pemahaman umum, in al berlaku pada proses penurunan Alqur'an secara sempurna, sedangkan tan iil pada proses penurunan Alqur'an secara bertahap. ${ }^{37}$

Makna tersebut bagi Syahrur bermasalah, karena orang juga akan bertanya, bagaimana Allah menurunkan besi dengan kata anzala dalam ayat lain?. ${ }^{38}$ Syahrur menakwilkan lafal inzal dan tanzil' dengan bantuan analisis saintifik, yakni dengan makna perpindahan objek material (naqlab al-madiyah) Alqur'an yang berlangsung di luar kesadaran manusia, seperti transmisi gelombang (an-naql bi al-amwaj). ${ }^{39}$ Inæal dan tanæil bukanlah proses penurunan, melainkan proses transformasi pengetahuan. Alqur'an

33 Abdul Mustaqim, Epistemologi Tafsir Kontemporer, 208.

34 Az-Zahabi, Altafsir Wa Almufassirun, 1:15.

35 Abdul Mustaqim, Epistemologi Tafsir Kontemporer, 212-214.

36 Komaruddin Hidayat, Memahami Bahasa Agama: Sebuah Kajian Hermeneutik (Jakarta: Paramadina, 1996), 215.

${ }^{37}$ Lihat penafsiran Syahrur mengenai Q.S al-Qadr dan al-isra' 106. Muhammad Syahrur, Alkitab Wa Alqur'an; Qira'ah Almu'asirah, 152-153.

38 Muhammad Syahrur, Alkitab Wa Alqur'an; Qira'ah Almu'asirah, 147.

39 Muhammad Syahrur, Alkitab Wa Alqur'an; Qira'ah Almu'asirah, 153. 
yang ada di alam malakut pada wilayah sama' ad-dunya ini dipindahkan/ ditransformasikan ke wilayah Insaniah, di mana tempat Nabi Muhammad SAW hidup. Sehingga, bagi Syahrur Alqur'an tidak diturunkan (sebagaiman kita pahami menurunkan barang dari atas ke bawah), melainkan ditransformasikan.

\section{Syahrur dan Skema Intepretasi Modern bagi Alqur'an}

Syahrur memahami Islam sebagai membuat suatu usaha rasional yang serius untuk membaca dan menggali kembali makna yang ada di dalam setiap lafal ayat Alqur'an. Upaya rasionalisasi ini yang kemudian dapat ditempuh dengan melakukan tafsir yang dibantu dengan analisis ilmu lain. Sehingga tafsir yang dihasilkan bernuansa integratif, memadukan keilmuan teks Alqur'an dengan sains. Dengan intelektualitas yang dimiliki, Syahrur bermain dalam bingkai teks, termasuk analisis sistematis-paradigmatis, dan memetakkan pemetaan hukum dalam ayat melalui teori batas matematika, dan menakwilkan kognisi klasik mengenai ayat mutasyabihat dengan rasionalitas sains modern sebagai salah satu manifestasi pemikiran kaum Islam saat ini. Dengan demikian, bagi Syahrur ilmu-ilmu alam dan sosial menyatu, menyapa, berinteraksi satu sama lain, termasuk berinteraksi dengan ilmu Alqur'an.

Aktivitas dan alur teori interpretasi Syahrur, jika diskemakan, dapat dilihat sebagai berikut: 


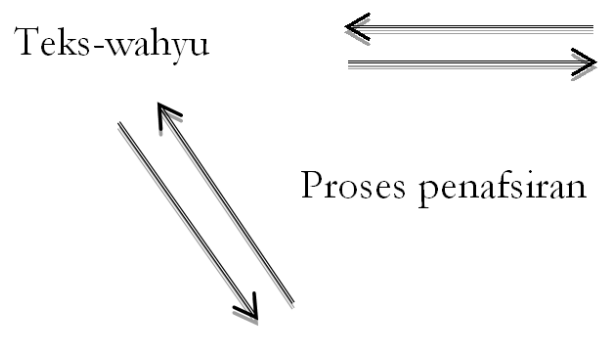

Akal/Ijtihad

Realitas kontemporer
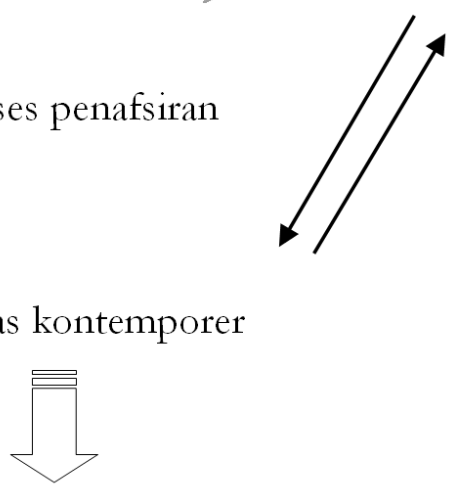

a. Produk tafsir bersifat tentatif, temporal, relatif.

b. Tidak ada tafsir yang final, semua bisa dikritisi dan dikaji ulang.

c. Tafsir merupakan hasil kreatifitas manusia.

d. Tafsir pada prinsipnya harus mampu memberikan solusi dan jalan terang bagi permasalahan kontemporer.

\section{Tentang Asma' Alqur'an}

Asma' Alqur'an (nama-nama Alqur'an) masih menjadi objek menarik bagi penelitian tafsir kontemporer, seiring dengan lahirnya beragam prinsip dan metode penelitian tafsir. Beberapa tema yang sudah bertahan lama dalam pemahaman kaum Muslim mulai dikaji kembali, salah satunya adalah tema tentang asma' Alqur'an. Konsepsi umum masyarakat Muslim sejak lama misalnya, menganggap bahwa lafal Alkitab, Albuda, Alfurqan dan lainnya merupakan nama lain dari kitab Alqur'an yang tidak perlu dipermasalahkan lagi.

Bagi Syahrur, konsepsi di atas bisa ditafsirkan ulang, dengan menafsirkan kembali kata tersebut yang tertuang dalam berbagai ayat Alqur'an. Teori yang digunakan dalam membangun konsep yang benar mengenai Alqur'an adalah "diferensiasi". Dengan teori ini, Syahrur mencoba memahami kembali apa yang disebut dengan "Alqur'an", serta menempatkan makna yang spesifik terhadap beberapa asma' Alqur'an. ${ }^{40}$

40 Muhammad Syahrur, Alkitab Wa Alqur'an; Qira'ah Almu'asirah, 46. 
Dalam membangun konsepsi mengenai Alqur'an, Syahrur mengawali ide besarnya dari uraian mengenai wahyu Alqur'an, dengan memetakkan wahyu yang diturunkan oleh Allah kepada Nabi Muhammad SAW. Syahrur mengistilahkan wahyu yang diturunkan oleh Allah dengan sebutan tanzil Alhakim, yang mengandung dua pengertian: kitab risalab dan kitab nubuwwah. Pembagian dua makna ini akan membantu dalam menentukan metode mana yang lebih tepat dalam menafsirkan ayat Alqur'an. ${ }^{41}$

Syahrur sendiri membedakan antara Alqur'an dan mushaf. Dua istilah yang dianggap sinonim ini, bagi Syahrur memiliki aksentuasi (penekanan) yang berbeda. Hal ini terlihat dari segi kebahasaan (lughawiyah). Syahrur membahasakan mushaf dengan istilah Alkitab, yaitu tema (maudhu') atau himpunan dari berbagai tema. Secara bahasa, lafal kitab dalam bentuk nakirahnya (indifinite) tidak merujuk kepada seluruh kandungan mushaf. Hal ini berbeda dengan lafal kitab ketika berbentuk ma'rifah (definite) dengan tambahan lam ta'rif menjadi Alkitab. Maknanya merujuk kepada seluruh himpunan tema-tema yang diwahyukan kepada Muhammad SAW. Dengan analisis ini, Syahrur lebih memilih menyebut mushaf yang diwahyukan kepada Nabi Muhammad SAW sebagai Alkitab, karena memiliki sejumlah muatan kitab atau tema tertentu yang sangat banyak.

Pewahyuan Alkitab inilah yang membentuk Nabi Muhammad SAW sebagai seorang Rasul sekaligus Nabi. Muatan tema (kitab) dalam mushaf (al-kitab) menurut Syahrur dapat diinventarisasi dalam dua tema besar, yaitu: tema yang mencakup unsur-unsur kenabian (nubuwwah) atau disebut juga kitab an-nubuwwah, dan tema yang mencakup unsur-unsur kerasulan (risalah) atau disebut juga kitab ar-risalah. Dengan demikian, konsepsi umum Alqur'an dalam pandangan Syahrur bergeser sedikit dari pandangan umum ulama. Menurutnya, Alqur'an adalah sebuah tema, sedangkan mushaf atau Alkitab adalah kumpulan dari berbagai tema yang ada di dalamnya. Berikut penjelasan dari kitab an-nubuwwah dan kitab ar-risalah.

${ }^{41}$ Muhammad Syahrur, Alkitab Wa Alqur'an; Qira'ah Almu'asirah, 269. 


\section{Kitab an-nubuwwah.}

Muatan mushaf terbagi menjadi dua: Alqur'an dan as-Sab' al-Mathani. Secara garis besar, tema-tema ini mengandung pembahasan mengenai pengetahuan alam, sejarah, dan bukti hakikat eksistensi objektif yang diwujudkan dalam ayat-ayat mutasyabihat. Dengan penekanan pada muatan mushaf, Syahrur memiliki definisi sendiri mengenai Alqur'an, yaitu sebagai bagian dari mushaf ALkitab, dan bagian dari tema wahyu kitab an-Nubuwwah.

Syahrur mengutip Q.S. Albaqarah: 185 yang menjelaskan mengenai Alqur'an yang diturunkan sekaligus dalam bahasa Arab pada bulan Ramadan sebagai Albuda dan Alfurqan, bukan sebagai penentu halal-haram. Dalam istilah "Alqur'an", tidak terdapat hal-hal yang berkaitan dengan perilaku manusia, seperti: ibadah, akhlak, nasehat serta yurisprudensi Islam. Pembedaan term Alqur'an dan ALkitab bagi Syahrur berasal dari pembagian yang dilakukan oleh Alqur'an sendiri. Karena itu, Alqur'an menurut Syahrur memberikan petunjuk kepada manusia, sedangkan Alkitab (Alqur'an dalam konsepsi umum) memberikan petunjuk kepada orang Islam (Almuttaqin). ${ }^{42}$ Dalam hal ini Syahrur menulis ${ }^{43}$ :

"Kembali kepada firman Allah SWT di awal surat Albaqarah, "itulah al-kitab tiada keraguan didalamnya, petunjuk bagi orang yang bertaqwa" dan firman Allah SWT dalam surat Albaqarah "bulan Ramadan diturunkannya Alqur'an sebagai petunjuk bagi manusia dan penjelas dari buda dan furqan.

Kita perhatikan ketika menyebut kata "al-Kitab" itu mengarah kepada petunjuk bagi orang yang bertakwa, karena dalam kitab itu memuat hukum-hukum, ibadah, mu'amalah dan akhlak, ada nilai ketakwaan yang disandarkan pada Alqur'an.

Dan ketika menyebut Alqur'an, dilanjutkan dengan ungkapan "petunjuk bagi manusia". Lafal manusia mencakup orang yang betakwa maupun yang tidak, maka orang yang bertakwa adalah bagian manusia, namun tidak semua manusia itu bertakwa, dan inilah poin keharusan untuk membedakan antara Alkitab dan Alqur'an."

42 Muhammad Syahrur, Alkitab Wa Alqur'an; Qira'ah Almu'asirah, 57.

${ }^{43}$ Muhammad Syahrur, Alkitab Wa Alqur'an; Qira'ah Almu'asirah, 57. 
Wujud tema ayat-ayat dalam kategori kitab an-nubumwah ini adalah ayat mutasyabihat. Namun, Syahrur memiliki definisi sendiri mengenai ayat atau kitab mutasyabihat. Ia membaginya menjadi dua: (1) Aljuz'u ath-Thabit (bagian yang tetap dan tidak pernah mengalami perubahan). Ayat dalam mushaf yang bertemakan kaidah-kaidah umum yang mengatur semua alam, mulai dari penciptaannya hingga kiamat masuk dalam kategori ini. Dalam pandangan ulama pun demikian, perdebatan mengenai deskripsi akhirat masih menjadi bahan permasalahan teologis. (2) Aljuг'u al-Mutagayyirat (bagian yang dapat berubah). Ayat dalam mushaf yang membahas peristiwaperistiwa alam yang spesifik seperti perubahan angin, bencana alam, serta peristiwa-peristiwa historis lainnya masuk dalam kategori ini. Bagi Syahrur, ayat-ayat yang termasuk dalam kategori ini (mutasyabihat) terbuka untuk ditakwilkan sesuai dengan perkembangan ilmu. ${ }^{44}$

\section{Kitab Alrisalah.}

Muatan mushaf dalam bagian ini terdiri dari kitab ayat mubkamat, atau disebut juga dengan umm Alkitab (induk kitab). Secara garis besar, tematema dalam kitab ini berisikan kaidah moralitas (kode etik) bagi manusia, berupa ibadah, muamalah, dan akhlak. Lebih spesifik lagi, kitab yang berisi risalah Muhammad SAW. ini terdiri dari tiga bagian utama: ibadah (ritual), akhlak (suluk al-insani) dan undang-undang (hukum). Manurut Syahrur, jika bagian risalah yang pertama dan kedua (ibadah dan akhlak) bukanlah lahan untuk berijtihad, maka tidak demikian halnya bagian ketiga (hukum). ${ }^{45}$ Dalam ayat hukum, Syahrur memiliki teori interpretasi sendiri, yang dikenal dengan teori batas (nazariyat Albudud). Pembagian dan gagasan muatan mushaf ini dituliskan secara tegas oleh Syahrur:

44 Muhammad Syahrur, Alkitab Wa Alqur'an; Qira'ah Almu'asirah, 56-57.

45 Muhammad Syahrur, Alkitab Wa Alqur'an; Qira'ah Almu'asirah, 51-56. Ahmad Zaki Mubarok, Pendekatan Struktualisme Linguistik dalam Tafsir Alqur'an Kontemporer Ala Syahrur, 153. 
"Dan karena Rasulullah SAW adalah seorang rasul sekaligus Nabi, maka kitab_-wahyu—yang diwahyukan kepadanya mencakup risalah dan nubuwwah-nya. Maka risalah adalah kumpulan pemberitahuan yang mewajibkan manusia terikat dengannya, meliputi: ibadah, mu'amalah, akhlak, halal-haram yakni sebagai taklif (kewajiban yang dipertanggung jawabkan). Dan nubuwwah yakni kumpulan penjelasan-penjelasan yang memuat pemberitahuan kauniah dan sejarah, haq-bathil." Karena itu, maka Alkitab memuat dua kitab pokok: Kitab pertama, kitab nubuwwah yang memuat penjelasan atas hakikat kejadian obyektif dan membedakan haq dan bathil atau hakikat dan keraguan. Kitab kedua, kitab risalah yang meliputi kaidah-kaidah tabi'at kemanusiaan dan membedakan halal-haram." ${ }^{46}$

Arah semantik pembagian muatan tema yang ada dalam mushaf (al-kitab) serta pembacaan ulang beberapa istilah kunci yang selama ini dipahami sinonim, bagi Syahrur menjadi agenda interpretasi yang penting. Istilah tersebut pada kenyataannya membawa muatan makna masingmasing, yang secara spesifik bisa dibilang terkait, namun terdapat pula makna aksentuatis yang perlu diperhatikan. Bagi Syahrur misalnya, istlah az-Ziker bukan nama Alqur'an, ia merupakan sebuah proses transformasi Alqur'an dari tahapan pra-linguistik menjadi berbentuk linguistik yang dapat dipahami oleh sistem bahasa manusia, bahasa Arab. Syahrur menulis:

"Driker adalah pemindahan/perubahan Alqur'an menjadi shigat bahasa manusia yang dilantunkan dengan lisan arab, dan ini adalah shigat yang disebut dengan Alqur'an". ${ }^{47}$

Kutipan di atas memperlihatkan bahwa lafal az-Zikr lebih tepat dimaknai sebagai proses pewahyuan Alqur'an, ketimbang dimaknai sebagai nama lain dari Alqur'an. Adapun Alfurqan yang dikonsepsikan sebagai nama Alqur'an, menurut Syahrur merupakan bagian dari umm Alkitab serta bagian dari kitab ar-risalah yang berupa sepuluh wasiat (Alwasaya al'Asyr), atau disebut juga sebagai sirat al-mustaqim yang termuat dalam surah

\footnotetext{
46 Muhammad Syahrur, Alkitab Wa Alqur'an; Qira'ah Almu'asirah, 56.

47 Muhammad Syahrur, Alkitab Wa Alqur'an; Qira'ah Almu'asirah, 51-56.
} 
Alfatihah. ${ }^{48}$ Posisinya tetap sama dengan ciri umum kitab risalah, yakni masalah ibadah, etika moral, dan ajaran agama. Berdasarkan perincian di atas, Syahrur menyimpulkan adanya perbedaan antara istilah Alkitab, Alqur'an, az-Ziker dan Alfurqan. Masing-masing istilah ini merupakan bagian dari tema pewahyuan serta menunjuk pada sesuatu yang berlainan dengan aksentuasi masing-masing. ${ }^{49}$

Skema konsepsi populer dan konsepsi Syahrur mengenai Alqur'an dan pembagiannya: ${ }^{50}$

\section{Skema I}

"Konsepsi Populer Mengenai Alqur'an"

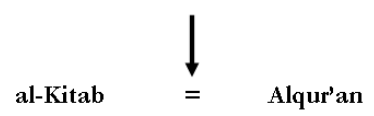

“Konsepsi Syahrur Mengenai Alqur'an"

Almushaf (Kopian dari Alkitab)

Aldzikr (Bahasa Pengucapan Alkitab)
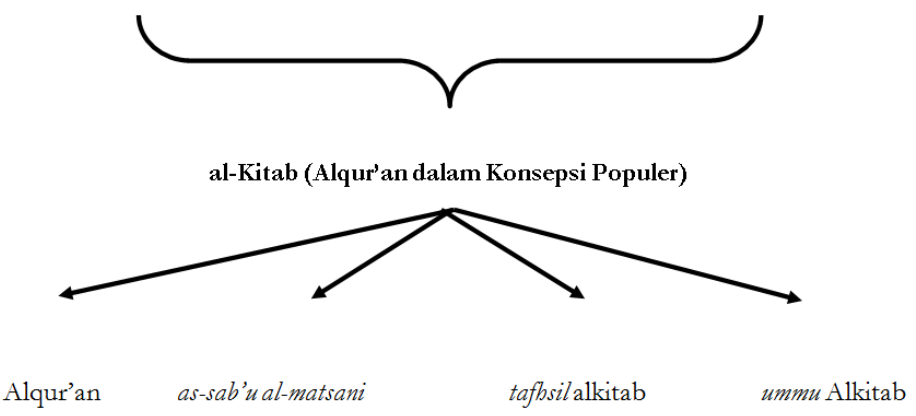

48 Muhammad Syahrur, Alkitab Wa Alqur'an; Qira'ah Almu'asirah, 65.

49 Ahmad Zaki Mubarok, Pendekatan Struktualisme Linguistik Dalam Tafsir Alqur'an Kontemporer Ala Syahrur, 149-151.

50 Andreas Christmann, "The Form is Permanent But The Content Moves; The Qur'anic Text and It's Interpretation in Muhammad Syahrour's Al-Kitab Wa Alqur'an,' in Modern Muslim Intelectual and The Qur'an, ed. Suha Taji Farouki (New York: Oxford University Press, 2004), 269-273. 
Skema II

"Konsepsi Populer Mengenai Muhkam dan Mutasyabih"

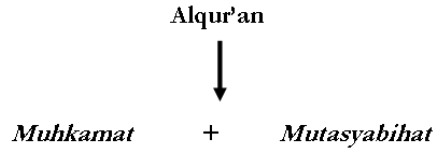

"Konsepsi Syahrur Mengenai Muhkam dan Mutasyabih"

Alkitab

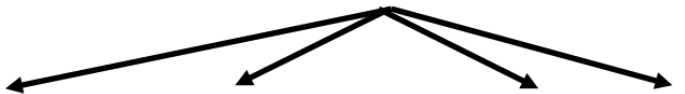

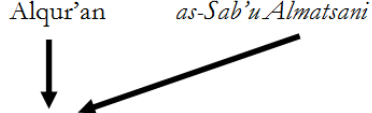

Mutasyabihat

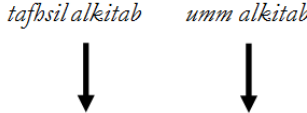

la Mubkam wa la Mutasyabib Mubkamat

\section{Skema III}

"Konsepsi Populer Mengenai Nubuwah dan Risalah"

$$
\text { Alqur'an }
$$

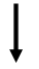

$$
\text { Nubuwwah = Risalah }
$$

"Konsepsi Syahhrur Mengenai Nubuwah dan Ar-Risalah"

$$
\text { Alkitab }
$$
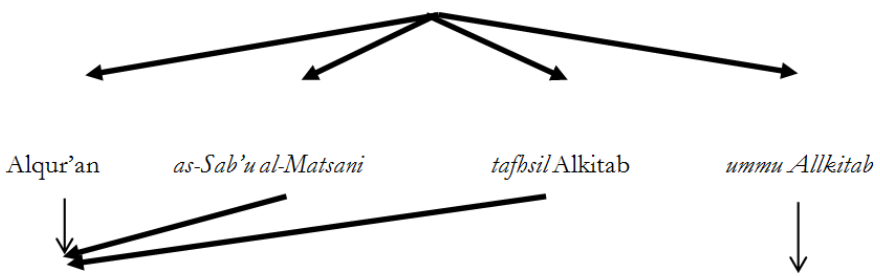
Muatan Masing-masing konsepsi Mengenai Alqur'an

Menurut Muhammad Syahrur

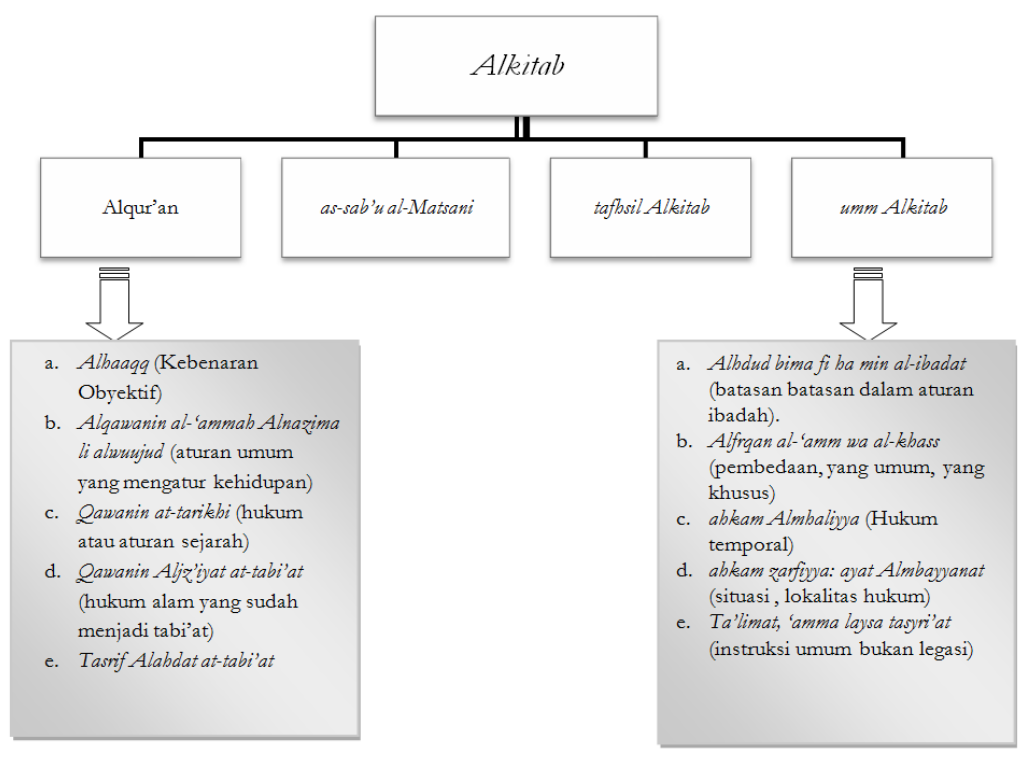

\section{Penutup}

Syahrur merupakan salah satu mufassir kontemporer yang hadir menawarkan gagasan tafsir Alqur'an modern dengan sentuhan analisis matematika (matematic analysis) dan sains (scientific analysis). Analisis matematika digunakan sebagai pola analisis dalam memetakan ayat-ayat hukum, sedangkan analisis sains digunakan sebagai metode menakwilkan ayat mutasyabihat.

Syahrur hadir menawarkan paradigma integratif dalam menafsirkan Alqur'an, paradigma yang dibangun dengan memadukan ilmu sains sebagai bagian dari keilmuan modern, dengan ilmu teks Alqur'an sebagai manifestasi ilmu klasik. Hal demikian terlihat dari banyaknya teori tafsir yang digagas dengan integrasi ilmu lain, seperti: teori albudud (teori batas) yang diramu dari analisis bahasa dan pemetaan hukum dalam ayat berdasarkan rumus matematika, serta menawarkan ta'wil 'ilmi menakwilkan 
Alqur'an dengan analisis bantu ilmu sains sebagai manifestasi berfikirnya kaum Muslim modern.

Tafsir bagi Syahrur setara dengan ijtihad, sama-sama usaha mencari dan mengeluarkan daya memahami teks agama. Tafsir digunakan dalam memahami dalam ayat-ayat mubkamat, dalam kategori kitab ar-risalah. Tafsir atau ijtihad bagi Syahrur guna memahami kitab ar-risalah, dengan ini maka untuk memahami pesan risalah tersebut haruslah menggunakan metode yang sesuai dengan perkembangan konteks dan zaman-termasuk perkembangan keilmuan misalnya menggunakan analisis matematika dalam memetakkan batas hukum, hak dan kuantitas pembagian warisan, menentukan batas aurat dan lain-lain.

Adapun ta'wil, Syahrur menggunakannya dalam obyek ayat-ayat mutasyabihat yang masuk dalam kategori kitab an-nubuwwah. Ta'wil yang dimaksud Syahrur adalah ta'wil 'ilmi atau ta'wil saintifik. Ayat-ayat yang masuk dalam kategori mutasyabihat—-termasuk Alqur'an-bagi Syahrur harus ditakwilkan sesuai dengan perkembangan pengetahuan manusia. Ta'wil itu semacam melakukan rekognisi atau bayangan ulang, guna memahamkan sebuah makna/fenomena dalam Alqur'an. Dengan itu, maka mufassir perlu menganalisis imajinasi konteks sosial masyarakat. Seperti menakwilkan proses turunnya Alqur'an dengan logika sains modern, bahwa menurunkan itu tidak mesti deskripsi atas ke bawah, namun mentransformasikan (dengan nuansa transformasi gelombang) merupakan bagian dari proses penurunan Alqur'an ketika diturunkan, bagi Syahrur mengambil posisi transformasi dari Allah SWTT ke Muhammad SAW melalui Jibril, bukan menurunkan langsung kitab dari atas ke bawah.

Demikian yang disebut dengan Qira'ah Almu'asirah (pembacaan baru) oleh Syahrur, pembacaan integratif terhadap Alqur'an yang memainkan perpaduan analisis ilmu tafsir sebagai pemahaman ilmu awal dengan analisis matematika/sains yang mewakili pemahaman atau pemikiran kekinian. 


\section{Referensi}

Az-Zahabi, Muhammad Husein. Altafsir Wa Almufassirun. Cairo: Maktabah Wahbah, n.d.

Christmann, Andreas. "Read the Qur'an as if It Was Revealed Last Night: An Introduction to Muhammad Shahrur's Life and Work." In The Qur'an, Morality and Critical Reason, edited by Andreas Christmann, xvii-xviii. Leiden: Brill, 2010.

. "The Form is Permanent but The Content Moves." In The Qur'an, Morality and Critical Reason, edited by Andreas Christmann, 263-264. Leiden: Brill, 2010.

. "The Form is Permanent but The Content Moves; The Qur'anic Text and It's Interpretation in Muhammad Syahrour's Al-Kitab Wa Alqur'an." In Modern Muslim Intelectual And The Qur'an, edited by Suha Taji Farouki, 269-273. New York: Oxford University Press, 2004.

Eickelman, Dale F. "Interview with Muhammad Shahrur." In The Qur'an, Morality and Critical Reason: The Essential Mubammad Shabrur, edited by Andreas Christmann, 502. Leiden: Brill, 2010.

Hidayat, Komaruddin. Memahami Bahasa Agama: Sebuah Kajian Hermeneutik. Jakarta: Paramadina, 1996.

Kurdi, dkk. Hermenetika Alqur'an dan Hadith. Yogyakarta: Elsaq Press, 2010.

Mubarok, Ahmad Zaki. Pendekatan Struktualisme Linguistik dalam Tafsir Alqur'an Kontemporer Ala Syahrur. Yogyakarta: Elsaq, 2007.

Mustaqim, Abdul. Epistemologi Tafsir Kontemporer. Yogyakarta: LKiS, 2010. , dkk. Studi Alqur'an Kontemporer. Yogyakarta: Tiara Wacana, 2002.

Rahman, Fazlur. Tema-Tema Pokok Alqur'an. Bandung: Pustaka, 1983.

Syamsuddin, Sahiron, dkk. Hermeneutika Alqur'an Madrab Yogya. Yogyakarta: Islamika dan Forstudia, 2003.

Syadzily, Ahmad Fawaid. "M. Syahrur; Figur Fenomenal dari Syiria." islamlib.com. Last modified 2014. www.islamlib.com .

Syahrur, Muhammad. Alkitab Wa Alqur'an; Qira'ah Almu'asirah. Damaskus: al-Ahali li al-Tiba'ah wa al-Nasyr wa al-Tauzi', 1990. 
—. Nabwa Ushul Aljadidah Li Fiqhi Alislami; Fiqh Almar'ah. Damaskus: al-Ahali li al-Tiba'ah wa al-Nasyr wa al-Tauzi', 2000.

Wijaya, Aksin. Arah Baru Studi 'Ulum Alqur'an: Memburu Pesan Tuban di Balik Fenomena Budaya. Yogyakarta: Pustaka Pelajar, 2009. 
Abdul Malik

AL-A'RAF - Vol. XIV, No. 1, Januari - Juni 2017 